\title{
Household Debt and the Rise of Financial Fragility in the Tunisian Context
}

\author{
Lobna Abid $^{1}$, Med Nejib Ouertani ${ }^{2} \&$ Sonia Zouari-Ghorbel ${ }^{3}$ \\ ${ }^{1}$ Faculty of Economic Sciences and Management of Sfax, Tunisia \\ ${ }^{2}$ Al-Imam Mohamed Ibn Saud Islamic University, Riyadh, Saudi Arabia \\ ${ }^{3}$ Higher Institute of Business Administration of Sfax, Tunisia \\ Correspondence: Lobna Abid, Faculty of Economic Sciences and Management of Sfax, Tunisia. E-mail: \\ lobnabid@yahoo.fr
}

Received: October 4, 2015

Accepted: November 3, $2015 \quad$ Online Published: December 25, 2015

doi:10.5539/ijef.v8n1p58

URL: http://dx.doi.org/10.5539/ijef.v8n1p58

\begin{abstract}
This paper aims at studying the financial vulnerability of the Tunisian household and the extent to which indebtedness is associated with increased "financial fragility", as measured by the household arrears' sensitivity to macroeconomic shocks. In addition, the paper tries to examine whether financial fragility is actually affected by macroeconomic variables. These issues are investigated by applying panel data modeling and vector-error correction mechanisms for household arrears. Overall, the analysis shows the importance of macroeconomic data in determining the household's financial fragility.
\end{abstract}

Keywords: household non-performing loans, financial fragility, panel data, cointegration

\section{Introduction}

Credit markets-related research focuses thoroughly on lending firms practices, while households are primarily considered as fund suppliers rather than debtors. However, recent events have highlighted that lending to households has taken a great part in banks' balance sheets and other financial intermediaries, as well as in the financial markets' operation along with the real economic activity. The ongoing sub-prime lending crisis shows the major importance of the household credit market in determining both the financial system's stability and the rate of economic activity. It is worth noting that lending to households increased strongly in the US during the pre-crisis period (i.e. before 2007), and grew at an even faster pace in other developed countries. It was also spread in several emerging economies as one of the fastest growing segments of total credits (IMF, 2006). In this sphere, Vandome (2009) maintained that households were ascribed to reach a certain level of unsustainable indebtedness with regard to households' earnings leading to financial vulnerability. As a matter of fact, the 2008 financial crisis has revealed that the fact of understanding the determinants of lending to households and their solvency is a major procedure not only for market practitioners, but also for regulators and policy makers.

The US household credit has been accompanied by an increase of remarkable insolvencies during the last two decades. Hence, the unsecured household debt in recent years may be inconsistent with the optimal behavior of intertemporal consumption and then, it should be rather associated with prevailing financial and economic difficulties of indebted households (Vandome, 2009). Hence, it is vital to wonder whether this correlation is only specific to the US recent experience, or it also applies to other countries. In other words, it is worth wondering if the highly-indebted households are more "financially sensitive" to payment default, especially when they are struck by adverse shocks as unemployment or interest-rate increases.

This paper deals with two central issues. Firstly, we use cross-banking data in order to study the determinants of household credit. Secondly, we resort to panel data modeling on household non-performing loans (NPLs) provided by sixteen Tunisian banks with regard to macroeconomic variables. Robustness checks are conducted by means of vector error-correction estimates.

Scholars, such as Jappelli et al. (2008), assume that insolvencies are generally linked with larger household indebtedness. Indeed, our results validate their hypothesis of financial fragility. Let us notice that panel data estimates on insolvencies reveal that the Tunisian banks (having experienced a relatively fast debt growth) have also encountered larger insolvency-rate increases. Moreover, the banks' specific variables are maintained to 
represent significant determinants of households' debts. Our panel regressions demonstrate that macroeconomic variables largely affect the level of household debts.

The remainder of the paper is organized as follows. Section 2 reviews the major determinants of household-debts and their NPLs. Section 3 presents a review of the literature related to household financial fragility. Section 4 ensures detailed information about the adopted methodology in this paper. Section 5 presents the sample data and describes the major variables used in this model. Section 6 displays the empirical results and their interpretation. Section 7 is reserved to the conclusion and to some recommendations which could be considered as useful advices for future of the banks.

\section{Determinants of Household Debt and Non-Performing Loans}

\subsection{Demand-Based Items}

In connection with the life-cycle pertaining model, households often tend to borrow in accordance with their forecasts future income growth, or simply to purchase goods such as properties, housing or consumer needs. As a country, Tunisia with a medium population-growth rate and a relatively large young household proportion is expected to show a high ratio of household debt to GDP. Moreover, households tend to borrow for the purpose of smoothing their transitory income changes. In fact, the household credit-market provides more resources as a temporary surplus to those in temporary deficit. If income inequality emerges as a result of short-term income shocks, then a positive association could occur between inequality measures and the household credit-market size. It is worth mentioning that a major inequality reason goes back to household-related future revenues, namely regular income fluctuations that enable the income inequality measures (such as the Gini Index) to appear as the most appropriate imperfect transitory-shock related proxies. A future variable having an impact on the household credit demand lies in the impetus generated by a convenient debt financing charge handling.

\subsection{Supply-Based Items}

The strong rivalry among banks has enhanced wider credit provisions and less costly loans and subscriptions by new applicants. Indeed, several studies have shown that loan-supplies usually rise in parallel with banks' deregulation procedures (such as the establishment of various offshoots across banks) along with banking liberalization in Europe as part of a national banking-restructuring policy and rehabilitation scheme (Bertrand, Schoar, \& Thesmar, 2007). Moreover, by granting loan access to lower-level debtors, higher banking rivalry might well result in a rise of the mean insolvency rate. Hence, such a relief in accessibility limitations has extended the credit scope to the available customers and also the once-rejected household clients. This situation justifies the increase by no less than a tenth in personal bankruptcy-level.

Previous literature on lending has exhibited a potentially-offsetting impact of an enhanced banking rivalry, i.e. the lending process is likely to fall while interest rates might increase once outside banks disprupt the predominant bonds with the prevalent relationships. As indicated by Peterson and Rajan (1995), loan-market rivaly appears to enhance the lenders' tendency to invest in constructing such relationships.

\section{Background about Household Financial Fragility}

Surveys dealing with households have focused on factors leading to household debt burden and financial distress. Research in this field has mainly contributed in clarifying loan commitments (secured and/or unsecured, i.e. mortgages and/or consumer credit). In this research area, when exploring issues concerning household "financial fragility", Jappelli et al. (2008) have perceived this phenomenon as one's inability to repay financial debt. Then, by using a self-reported indicator of financial distress, Del Rio and Young (2008) have analyzed unsecured household debt and have shown that they have indebtedness difficulties reflecting a given personal bankruptcy rate (Dick \& Lehnert, 2010).

Previous literature has also emphasized the fact that there is a fundamental link between subjective measures of financial distress and other indicators extending the probability of indebtedness (Del Rio \& Young, 2008). Moreover, the empirical findings have revealed that the ratio of unsecured debt to income is assumed to be an eminent factor determining financial instability. This has led researchers to conclude that significant changes in households' socio-economic characteristics are due to the fact that debt problems have remained constant over the period $1995-2000$.

It's worth mentioning that the previous findings have shown that the increase in unsecured young households' debt combined with a high debt-income ratio have resulted in a situation where the households became more vulnerable to potential financial shocks in their income and also to the increase in interest rates. In this context, homeowners and renters' indebtedness is analyzed not only at the level of the amount of household income which is devoted to paying back debts, but also in connection with the effects of households' debts (May et al., 


\section{4) (Note 1).}

Besides, Duygan and Grant (2006) have investigated the extent to which an adverse shock to household's income and the response to this adverse event were not homogeneous fo all countries. In fact, the responses generally depend on local financial institutions affecting the propensity to fall into arrears on mortgages and unsecured loans. Indeed, the empirical results have indicated that the adverse shocks (such as unexpected changes in income) intensify the possibility of arrears, by taking into account the amount indicating the cost of the payment default.

Moreover, the literature on households has revealed that Europeans aged 65 and above could be exposed to a financial fragility which is specific to certain parameters, such as country, age groups, health status, and other socio-economic determinants (Christelis et al., 2010). These authors have maintained that the availability of collateral, the weight of installment payments in disposable income, and the accumulated debt constitute the major factors determining household financial fragility. Therefore, when analyzing the determinants of debt burden, payment default and bankruptcy, Fay et al. (2002) as well as Brown and Taylor (2008) have empirically adopted household level data and have also introduced other socio-demographic and economic explanatory variables that comply with the aim and nature of their analyses.

While all the above authors were mainly centered on debt insolvency, Worthington (2006) as well as Bridges and Disney (2004) have dealt with an aspect of financial distress embodied in individuals' inability to engage in basic social activities. These authors have assumed that both the demographic and socio-economic characteristics of households and their debt portfolio contribute in shaping the financial distress.

Similarly, other studies were concerned with low-income families suffering from arrears' difficulties, default in both loan commitments and payment for housing and utilities (Bridges \& Disney, 2004). In an attempt to prove the extent to which the aggregate level of arrears was linked to specific household characteristics, some authors have recourse to the combination of the arrears data. Their objective was to find out that using credits and accumulating arrears vary from parents/couples to children, as they vary from homeowners to renters.

In this paper, we try to display a more outstanding definition of household financial fragility, always with reference to the works of Bridges and Disney (2004) as well as Worthington (2006). Such a definition requires highlighting the excess of indebtedness due to over-commitment, as well as focusing on other determinants of financial instability. These determinants range from the inability to face the monthly payment and balance the budget and arrears in paying utility bills to the difficulties in affording the expenses related to food or regularly paying the rent.

Hence, these households may be perceived as 'financially vulnerable' because they are mainly ascribed to adverse shocks (such as job loss, reduction in working hours, illness, and death). These chocks can alleviate the source of income and/or contribute in making unexpected liabilities, hence having a negative effect on households' financial situation. It is worth noting that unsound and/or unsustainable aspects of borrowing can be among the predominant factors of financial vulnerability, hence leading households to spend beyond their earning capacities.

In this respect, added to low levels of earnings and wealth, poor financial management and unreasonable life-style behaviors embodied in one's short-sightedness and irresponsibility can intensify the household tendency to unsustainable expenditures. Moreover, other equally important factors can play a key role in yielding households' indebtedness and mainly contributing in households' risky management. Among these factors, we may quote the adverse events and the absence of financial instruments such as lack of life insurance and/or other sorts of insurance policies.

In short, financial vulnerability is a multidimensional phenomenon which requires an analytical analysis allowing to discover its major and hidden causes. With regard to households' indebtedness and financial vunerability, we will present, in the following section, our adopted methodology, the description of the major targeted variables, and also the results and interpretations of the estimated Tunisian households.

\section{Methodology}

In this study, a dynamic panel (Error-Correction Model, ECM) model is applied in order to show the relationship between household financial fragility and some macroeconomic variables such as real interest rate, the ratio of total household debt to household disposed income, and the real disposed income per household. The econometric testing procedure is detailed in the following sub-sections. 


\subsection{Unit-Root Tests}

Several tests have been proposed in the literature. Among these tests, we may cite those that were applied by Levin; Lin and Chu (2002), Harris and Tzavalis (1999), Maddala and Wu (1999), Bai and $\mathrm{Ng}$ (2001), Chang (2002 and 2004), etc. However, the tests of Levin and Lin (1993) as well as Im, Pesaran and Shin (1997, 2002 and 2003) are the most well-known ones.

Nevertheless, the major limits noticed in the Levin and Lin's (1993) test lie in the autoregressive unit-root homogeneous character under the alternative hypothesis. Indeed, in case of the unit-root hypothesis rejection,

one could accept the unit-root autoregressive hypothesis, $\rho_{i}$, common to all individuals, once the usual specification test has been applied. Hence, Im, Pesaran and Shin (IPS, 1997, 2002 and 2003) have provided a contribution whereby this critical aspect could be met. In fact, these authors have developped a test enabling,

under the alternative hypothesis, not only the autoregressive unit-root heterogeneity ( $\rho_{i} \neq \rho_{j}$ ), but also the heterogeneity relevant to the presence of a unit-root within the panel. Therefore, Im, Pesaran and Shin (2003) have considered an individual-effect model with no deterministic trend.

Like the Levin and Lin's test, the IPS test is a joint test of the unit-root null hypothesis $\left(\rho_{i}=0\right)$ with no-individual effects,

$H_{0}: \rho_{i}=0, i=1, \ldots, N$

$H_{1}: \rho_{i} \prec 0, i=1,2, \ldots, N_{1} \quad$ since under the null hypothesis, $\alpha_{i}=0$.

$\rho_{i}=0, N_{1}+1, N_{1}+2, \ldots, N$

\section{The IPS test is:}

In the presence of unit-root for the time series, one might wonder if a long-term equilibrium relationship does exist among the selected variables. If this relationship is proven to be valid, then the cointegration technique seems appropriate.

\subsection{Cointegration Test}

Once the variable-integration order is identified via unit root testing, the next step consists in performing a cointegration test. In the presence of panel data, the main cointegration tests proposed in the literature were adopted by Pedroni (1995, 1997, 1999, 2003 and 2004), Kao (1999), and Bai and Ng (2001). They have used residual tests similar to those proposed by Engle and Granger (1987) within the time series framework. As for Larsson, Lyhagen and Lothgren (2001) as well as Groen and Kleibergen (2003), they have conducted tests which were based on the likelihood ratio within a system where the number of cointegration relationships was a priori unknown.

In this paper, the cointegration test of Pedroni (2004) takes into account the individual heterogeneity through the specific and pertinent parameters to each individual sample, in conformity with the IPS (2003) stationarity test. Such heterogeneity could be simultaneously located at the level of cointegration relationships, as well as at the short-term dynamics. Thus, under the alternative hypothesis, there should exist a cointegration relationship specific to each individual as it differs from an individual to another. As a matter of fact, the consideration of this heterogeneity constitutes an undeniable advantage since, in practice; for each individual, a cointegration vector is scarcely identical.

The implementation of Pedroni's test (2004) entails, in a first stage, the following long-term relationship estimation:

$$
y_{i t}=\alpha_{i}+\delta_{i t}+\beta_{1 i} x_{i t}+\ldots \ldots+\beta_{M i} x_{M i t}+\varepsilon_{i t}
$$

where $\mathrm{i}=1,2, \ldots, \mathrm{N}$ represents the individual, $\mathrm{t}=1,2, \ldots, \mathrm{T}$ designates time and $\mathrm{m}=1,2, \ldots, \mathrm{M}$ represent the explanatory variables.

In fact, Pedroni (2004) has proposed seven relevant tests, four of which were based on the "within" dimension 
and the other three tests were based on the "between" dimension. The two categories of tests rely heavily on the no-cointegration null hypothesis: $\rho_{i}=1$, where $\rho_{i}$ stands for the estimated residuals' autoregressive term, under the alternative hypothesis $\left(\hat{\varepsilon}_{i t}=\rho_{i} \hat{\varepsilon}_{i t-1}+v_{i t}\right)$.

\subsection{The Error Correction Model (ECM)}

Generally, in the case of cointegrated variables, the short-term relationship should be conducted on the basis of an ECM framework. Once the number of cointegration vectors' is determined, the ECM model can be estimated, as given by the following equation:

$$
\Delta L N P L_{i t}=\alpha_{i}+\delta_{i} \Delta x_{i, t}+\lambda_{i}\left(L N P L_{i, t-1}-\hat{\beta}_{i} X_{i, t-1}\right)+\varepsilon_{i, t}
$$

where:

$L N P L_{i t}$ designates the household financial fragility indicator of bank i for year $\mathrm{t}$,

$x_{i t}$ is the vector containing the exogeneous set of variables of bank i for year $\mathrm{t}$,

$L N P L_{i, t-1}$ stands for the household financial fragility indicator of bank i for year $\mathrm{t}-1$,

$\lambda_{i}$ is the adjustement coefficient or response term,

$\alpha_{i}$ et $\delta_{i}$ are the parameters to be estimated, and

$\Delta:$ is the difference operator.

The above mentioned equation is, simultaneously, a static model $\left(\delta_{i} \Delta x_{i, t}\right)$ and a dynamic one $\lambda_{i}\left(L N P L_{i, t-1}-\hat{\beta}_{i} x_{i, t-1}\right)$.

In fact, within a long-term relationship, the ECM helps integrate the short-term fluctuations. The in-panel ECM estimation does well confirm and corroborate Pedroni's test results $(1999,2004)$, maintaining the existence of a cointegretion relationship with respect to the different tested models.

\section{Sample Data and Description of the Major Used Variables}

\subsection{Sample Description}

The main variable deals with the size of household NPLs. The database covers 16 banks observed over the period 2003-2012. These banks represent $90 \%$ of the whole banking sector, and would serve to analyze the households' financial fragility. We propose to apply the size of the household NPLs with respect to the banking sector performance.

\subsection{Banking Data}

The analysis of the Tunisian banking data on household debt aims at highlighting it as compared to macroeconomic variables. In fact, the household ratios Debt/GDP are taken from the Tunisian Central Bank (TCB). It is worth mentioning that household debt varies dramatically over the period 2003-2012, as indicated in Figure 2 below. This justifies the legitimacy of investigating these noticeable cross-bank differences which are dependent on the rate of household lending.

\subsection{Descriptive Analysis of Household Financial Fragility Indicators}

This sub-section deals with the Tunisian household debts and their fragility resulting from an unfavorable economic shock, as in the case of job-losses, the rise of inflation rate, the non-performing loans etc. Besides these factors, there are other types of factors (such as serious ilnesses and deseases) which could significantly affect household incomes. As a result, we notice a negative effect on the personal financial stability. 
Hence, the global macro-economic data might provide a general overview of the Tunisian households' average financial situation. Such a financial situation is becoming worse for a number of reasons, such as:

Loss of wealth,

Rise of unpaid loans, and

High rates of unemployment and debt.

Indeed, an unexpected rise in the interest rates could enhance the debt weight and lead to other financial difficulties for the household. Thus, the impact tends to vary from one household to another, according to the type of the allocated loan, their respective arrear installments as well as the charged interest rate.

\section{- Loans to individuals}

Rrecently, this credit type of loans has continued to grow until reaching very high levels. Household credits that increased by $8.7 \%$ in 2012 (53.12 billion Tunisian dinars) as compared to 2011, have become more vulnerable due to an increase in loans allocated to individuals.

Figure 1 shows the registered rise in private loans allocated by Tunisian banks. We can easily notice the rapid rise of the credits' size over the period 2003-2012.

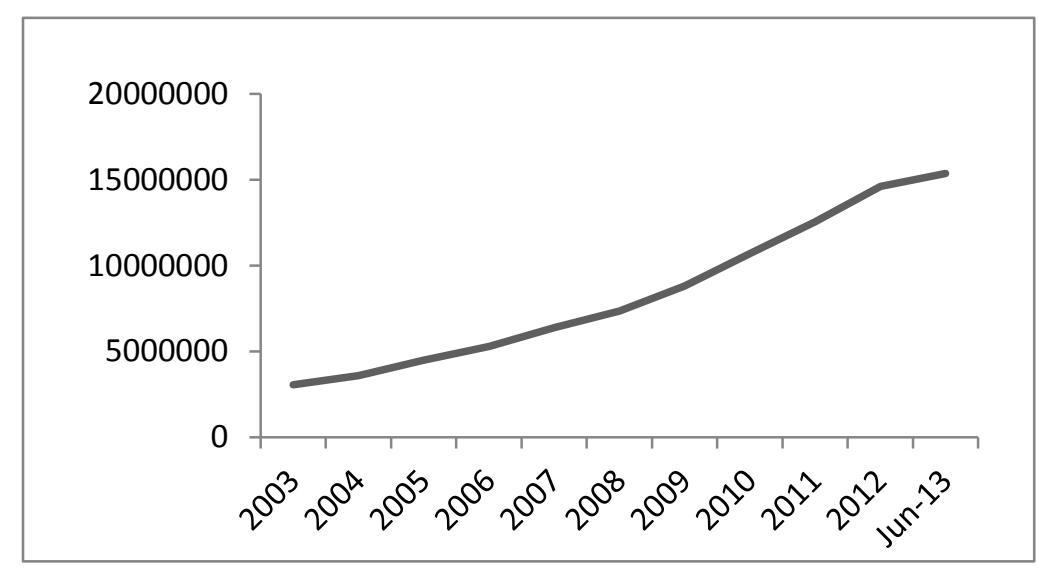

Figure 1. Loans to individuals

Source: TCB Financial Statistics.

In this context, a heavier debt level could be explained by the fact that a high-income proportion should be attributed to the debt service, whose weight is greatly influenced by the debt characteristics as well as the scheduled installments.

Hence, the rise in the household debt level highly goes beyond the individuals' reimbursment capacity and further aggravates their financial fragility, the asset decreasing value, and the rise of interest rates, which leads households to become increasingly more vulnerable.

\section{- The ratio of debt to household disposable income}

This ratio is just an indicator enabling to detect the household's solid or weak finacial state. In our case, this ratio has shown a continuous growth noticed over the period 2003-2011. Figure 2 illustrates such an evolution. 


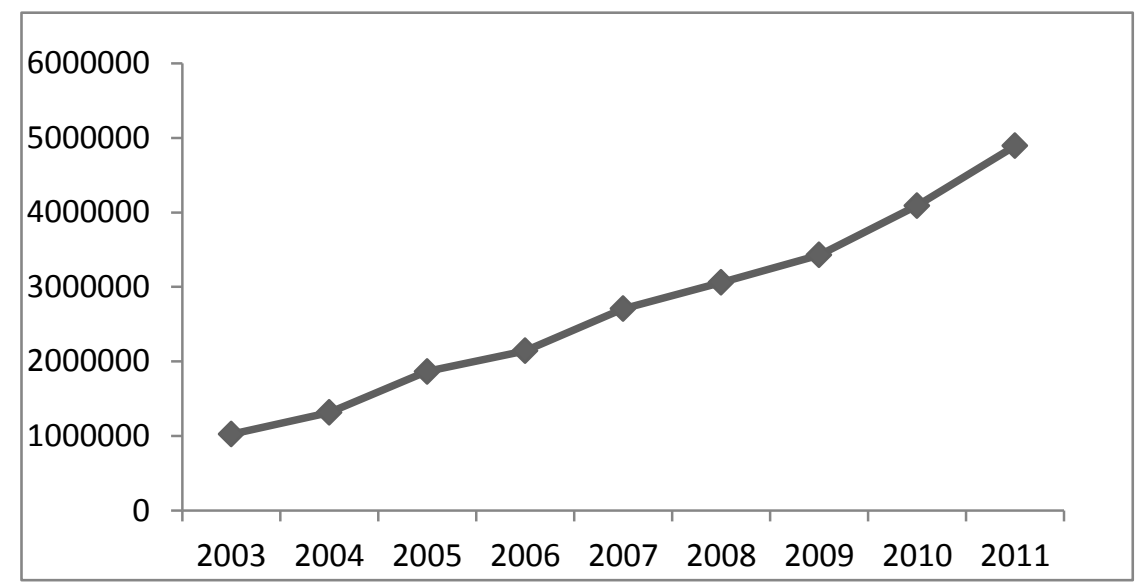

Figure 2. Debt/national disposable income per capita

Source: TCB Financial Statistics.

Similarly, this ratio obviously shows the Tunisian household's risky situation when confronted to the rise in household indebtedness level in recent years.

\section{- Debt/Gross Domestic Product Ratio}

In Tunisia, it is worth mentioning that households' debt relative to GDP has risen sharply since 2003. Figure 3 shows the extent to which the Debt to GDP ratio represents a financial measure that may have, in parallel, a negative effect on the financial situation of the households.

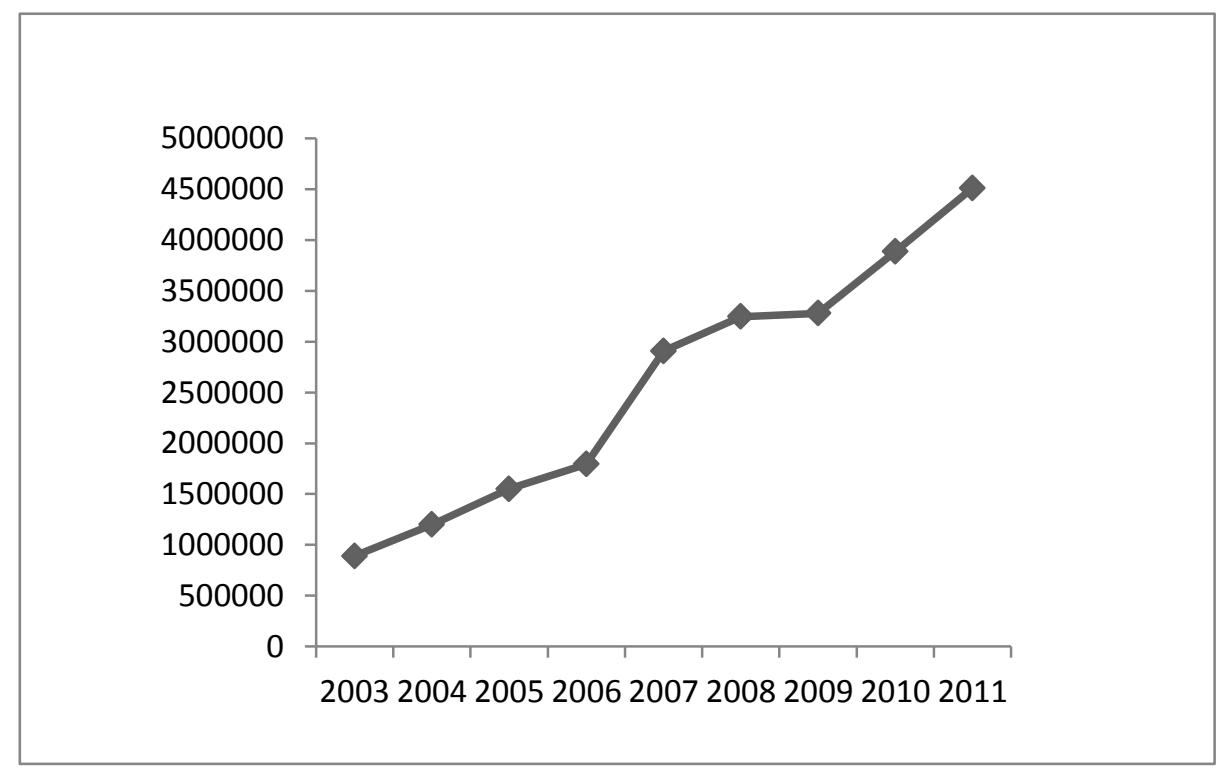

Figure 3. Debt/gross domestic product

Source: TCB Financial Statistics.

Therefore, the Debt/GDP constitutes an important ratio allowing to assess the degree of robustness of the different sectors as well as the whole economy. In short, the Tunisian households' financial vulnerability remains a serious problem.

\section{Household Financial Fragility Estimates: Results and Interpretations}

In this section, we propose to check whether the macroeconomic variables, as defined in the previous section, affect the households' financial fragility. We analyze data from 16 Tunisian banks observed over the period ranging from the first quarter of 2003 to the fourth quarter of 2012. The advantage of using a framework of panel 
data allows us to get enough observations, taking into account the unobserved heterogeneity between banks. To our best knowledge, this might be the first study dealing with this topic in the Tunisian context.

\subsection{Econometric Model Presentation}

To explain the Tunisian households' fragility, the following econometric model has been applied:

where,

$$
N P L_{i t}=\alpha_{0}+\alpha_{1} \text { Debt }_{i t}+\alpha_{2} \text { Income }_{t}+R L R_{t}+e_{i t}
$$

NPL: is the logarithm of the NPLs household ratio per bank,

Debt: is the logarithm of the household debt ratio to disposable income,

Income: is the logarithm of real household disposable income per capita (Note 2).

RLR: is the real interest rate, and

$e_{i t}=$ error term.

These represent the model's basic variables, as widely applied in the literature, trying to explain the households' financial fragility in Tunisia.

In fact, we assume that the NPLs' behavior constitutes a dynamic process in the sense that its previous level might well explain the present one. This is deduced from the fact that NPLs at time't' capture the cumulative amount of the prior periods of NPLs. In addition, the current NPLs ratio will certainly influence the banks' credit policy, hence affecting their future financial conditions' behavior and, therefrore, the NPLs ratio. Therefore, applying this specification turns out to be consistent with the relevant literature (Davis, 1995; Whitly et al., 2004).

Before proceeding with our model estimation, the unit root test needs to be conducted as a preliminary step.

6.1.1 Stationarity-Analysis Test

The results from the IPS (2003) unit root test are listed in Table 1:

Table 1. IPS (2003) unit root test results

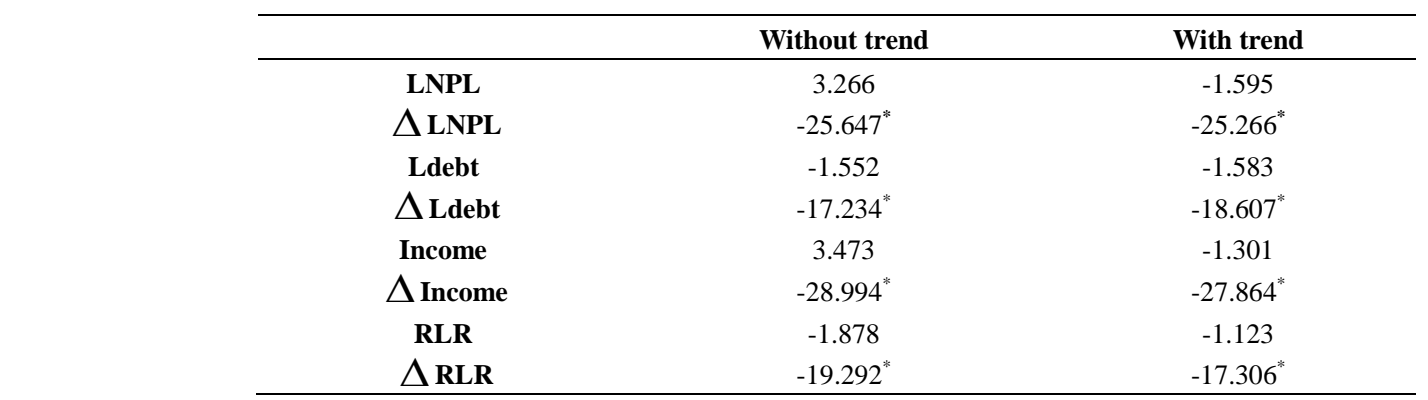

Note. ${ }^{*}$ significant at $1 \% ;{ }^{* *}$ significant at $5 \% ;{ }^{* * *} \quad$ significant at $10 \%$.

By applying this test on all the variables, in-level and in a first-difference, one might notice that all variables are non-stationary at a threshold of 5\%. Conversely, however, the series turn out to be stationary at the first-difference stage.

Subsequently, and after ensuring that all series are integrated in the same order I(1), we turn to test the possibility of a prevailing long-term linear relationship between these variables. This could be accomplished through applying a cointegration panel test.

At a primary-difference step, the unit-root hypothesis appears to be rejected for the entire set of the analysed variables. As a conclusion, one can notice that the whole panel series turns out to be integrated at an order of 1 , as already stated by the IPS (2003) statistics.

\subsubsection{Panel Cointegration Test}

Let us proceed with the panel cointegration test. The cointegration concept could be defined as a systematic long-term co-movement between two or more economic variables (Yoo, 2006). In this section, Pedroni's (1999, 2004) cointegration test is applied in order to check the existence of a long-term relationship among the NPLs 
ratio and its determinants. The results of the cointegration test are presented in Table 2.

Table 2. Pedroni's $(1999,2004)$ Cointegration test results

\begin{tabular}{lllc}
\hline \multicolumn{1}{c}{ Without trend } & \multicolumn{2}{c}{ With trend } \\
\hline Tests & Statistics & Tests & Statistics \\
\hline Panel $v$ Statistics & 0.42 & Panel $v$ Statistics & 0.24 \\
Panel $\rho$ Statistics & -2.26 & Panel $\rho$ Statistics & -1.18 \\
Panel pp Statistics AD(PP) & -2.73 & Panel pp (PP) Statistics & -1.46 \\
Panel Statistics & 1.27 & Panel (ADF) Statistics & 0.63 \\
Panel $\rho$ Statistics & -2.06 & Panel $\rho$ Statistics & -1.82 \\
Panel (PP) Statistics & -3.10 & Panel (PP) Statistics & -1.59 \\
Panel (adf) Statistics & 1.93 & Panel (adf) Statistcs & 0.99 \\
\hline
\end{tabular}

Note. ${ }^{*}$ significant at $1 \%,{ }^{* *}$ significant at $5 \%,{ }^{* * *}$ significant $10 \%$.

It is not surprising that most statistics do reject the no-cointegration null hypothesis since there exists a cointegration relationship between the indicator of household financial-fragility (households' non-performing loans) and of the fundamental variables. Overall, Table 2 reveals the existence of a cointegration relationship between the NPLs and the fundamental variables that were presented in our background discussion. These findings corroborate those obtained by Rinaldi and Sanchis-Arellano (2006).

From the econometrical point of view, and in presence of panel data, such a relationship can be further estimated by resorting to the Full Modified Least Square (FMOLS) method, as developed by Pedroni (1999).

\subsubsection{Estimation of the Cointegration Relationships}

It is worth highlighting that the fact of applying Pedroni's (1999) test would only serve to check the extent to which a cointegration relationship exists between the household non-performing loans and the applied variables. Once these tests confirm the cointegration of variables, the FMOLS estimation method could then be used.

Applying the cointegration test on panel data requires the adoption of an adequate estimation method. Accordingly, a variety of methods can be distinguished. Among these, we may cite, for instance, Pedroni's FMOLS, the Dynamic Least Square Method (DOLS), the Generalized Moments Method (GMM), and the Maximum Likelihood (ML). Several authors, such as Phillips and Moon (1999), have demonstrated that, in the presence of panel data, the FMOLS and DOLS methods lead to normally-distributed estimators. Moreover, Pedroni (1996) has shown that the Least Square Method estimators are considered as super-convergent and that their asymptotic distributions are biased and depend on the nuisance parameters. The author also states that these problems could be noticed due to the presence of heterogeneity.

The model estimation results via FMOLS are presented in Table 3.

Table 3. Cointegration vector estimation via FMOLS

\begin{tabular}{llcc}
\hline Bank & Variable & Coefficient & t-statistic \\
\hline \multirow{3}{*}{ All banks } & Ldebt & 1.103368 & 12.764872 \\
& RLR & 4.218530 & 2.217494 \\
& Income & 0.799982 & 1.850878 \\
\hline
\end{tabular}

Table 3 highlights the long-term relationship binding the NPLs to the macro-economic variables with regard to Tunisian banks. The second column of the Table indicates the estimated parameters.

As indicated, the ratio of household debt to income appears to have a significant positive effect on the probability of falling into long-term payment defaults. This indicator helps assess the households' financial capacity to fulfill their installments and to pay back their debts since the debt portion with respect to the household income seems to reflect well his real financial situation.

Thus, the households' high debt level with regard to incomes could result in serious financial problems, and thereafter, to household financial fragility (Rinaldi, 2006; Anderloni, 2012).

The households' financial situation becomes even more precarious if the interest rates turn out to represent a 
large portion of the income, just as it is the case when the assets' value with regard to liabilities for most households, as any decrease in their incomes would certainly affect their debt-reimbursement capacity, hence increasing their financial fragility.

As a matter of fact, income constitutes the only wealth component that figures in the equation. It represents a resource indicator held by households in order to finance their needs. In fact, the households' defect features provide a real view about the reasons of financial distress, and therefore, about the importance of debt. This fact reflects that a high debt level could well yield serious financial problems (Anderloni, 2012). However, and with respect to our case study, this variable wasn't shown to be significant. This could be explained by the fact that we are dealing with gross disposable income per capita. Furthermore, the real interest rate also appears to have a positive and significant impact on the household non-performing loans. When referring to the existing empirical literature, we find that the link between the real interest rate and the non-performing loans' ratio is positive. In this context, Bofondi and Ropele (2011) have demonstrated that an increase in the real interest rate would immediately result in an increase in the debt charge, generating a high increase of risky and doubtful installment reimbursement( i.e unpaid credits) and hence, a rise in household financial fragility.

As for the last stage, the focus is on estimating the assessment of the error-correction model in the short term.

\subsubsection{Sensitivity Analysis: Estimating The Panel Error-Correction Models}

For the sake of robustness checks, we apply the econometric dynamic panel techniques in order to estimate and evaluate the error-correction models (ECM), as applied in our sample.

Indeed, the ECM model is represented by the following equation:

$$
\Delta L N P L_{i t}=\alpha_{i}+\delta_{i} \Delta x_{i, t}+\lambda_{i}\left(L N P L_{i, t-1}-\hat{\beta}_{i} X_{i, t-1}\right)+\varepsilon_{i, t}
$$

where:

$\operatorname{LNPL}_{i t}=$ the household financial fragility indicator of bank $\mathrm{i}$ in year $\mathrm{t}$,

$X_{i t}=$ the vector encompassing the exogeneous variables' set of bank $\mathrm{i}$ in year $\mathrm{t}$,

$L N L_{i, t-1}=$ the household financial fragility indicator of bank i for the year $\mathrm{t}-1$,

$X_{i, t-1}=$ the vector containing the exogenous variables' set of bank i in year $\mathrm{t}-1$,

$\lambda_{i}$ : adjustment coefficient,

$\alpha_{i}$ et $\delta_{i}$ the estimated parameters,

$\mathrm{i}=1,2, \ldots . \mathrm{N}$ designates the banks, and $\mathrm{t}=1,2, \ldots . \mathrm{T}$ designates time.

This equation involves, simultaneously, a static model $\left(\delta_{i} \Delta x_{i, t}\right)$ along with a dynamic one $\lambda_{i}\left(L N P L_{i, t-1}-\hat{\beta}_{i} X_{i, t-1}\right)$.

Prior to treating the long-term relationship, the error-correction model is achieved in order to ensure the integration of the short-term fluctuations.

Indeed, the error-correction model (ECM) exhibits several advantages. On the one hand, the ECM estimation helps studying the short-term relationship between the indicator of households' financial fragility and the exogeneous variables as well as the speed at which all the variables resume the long-term equilibrium value.

On the other hand, the ECM estimation constitutes a suitable technique enabling to study the possibility that a short-term relationship between the indicator of households' financial fragility (NPLs) and its determinants reflects a phenomenon that is fundamentally different from that of a long-term relationship among variables. Such a result could be checked by using an adjustement coefficient $\hat{\lambda}_{i}$ (which is negative and significantly different from zero).

Moreover, the ECM estimation enables to ensure the presence of a long-term equilibrium relationship (i.e. a cointegration one) between the endogeneous variable and the exogeneous ones. In fact, the adjustment coefficient needs to be significantly negative. If this condition is not satisfied, then it will be better to avoid using 
an ECM type of specification. Rather, the error-correcting mechanism would tend towards the opposite trend and would, therefore, deviate from the long-term target. Indeed, as already mentioned, the cointegration relationship indicates that the model variables do follow a long-term equilibrium path though they might diverge from the equilibrium in the long-run. However, this divergence from the long-term sub-jacent relationship remains temporary and non-permanent.

In order to estimate the ECMs' indicator of household financial fragility with the pertinent explanatory variables, we consider applying the approach of Pesaran, Shin and Smith $(1996,1999)$. In this respect, three major techniques are worth to be adopted since they are expected to secure the estimation of the ECMs in the panel: (1) the dynamic fixed-effects estimator' (DFE), (2) the pooled mean group estimates (PMG), and (3) the mean-group estimates (MGP). With respect to our case study, we have opted for the DFE estimation technique (Note 3). The global sample ECM estimation results are illustrated in Table 4.

Table 4. ECM dependent variable: $\Delta$ NPL

\begin{tabular}{lllll}
\hline Variable & Coeff. & Std Error & T-Stat. & Signif. \\
\hline Constant & -4.363 & 0.455 & -9.574 & 0.000 \\
$\Delta$ debt & 1.032 & 0.088 & 11.693 & 0.000 \\
$\Delta$ RLR & -2.462 & 2.795 & -0.880 & 0.378 \\
$\Delta$ Income & 0.565 & 0.895 & 0.631 & 0.527 \\
RESIDS $(\hat{\lambda})$ & -0.279 & 0.028 & -9.821 & 0.000 \\
\hline
\end{tabular}

The ECM estimation results show the short-term relationship which exists between the endogeneous variable and the exogeneous ones. Indeed, the estimated ECM adjustment coefficient ( $\hat{\lambda}=-0.279)$ proves to be negative and significantly different from zero at $1 \%$ level. Moreover, the obtained results highlight that this adjustment coefficient appears to be statistically and significantly negative, justifying the existence of a long-term equilibrium relationship between the households' NPLs ratio and the macro-economic variables.

Similarly, the gross disposable income per household is positive and non-significant in the long run, whereas the real interest rate appears to bear a negative and non-significant sign. As a matter of fact, this finding contradicts Rinaldi et al. (2006) who have noted that the sign of this variable was positive and significant. Such effects are hard to perceive in the short run, owing to the fact that a long time period is necessary for an eventual complete full shock transmission to take place.

Therefore, the debt/income ratio appears to have a positive and significant effect in the short term as well as the long-term estimation. Hence, one can deduce that the rise in the debt/ /income ratio has ranked the household sector within a too risky financial situation. Indeed, such a major contributive risk-attenuation reason lies in the income increase, while in our case study, income has been shown to grow at a pace that is far lower than the debt size.

In short, one might notice that the in-panel ECM estimation corroborates and confirms the test results achieved by Pedroni $(1999,2004)$ concerning the existence of a cointegration relationships with regard to the tested model. This shows that the model takes into account the various factors leading to an increase in the size of NPLs. Indeed, the model has proved that, in the long run, the increase in the debt/income ratio has to be accompanied with an increase in the real disposable income. This indicates that the increase in real disposable income denotes a relatively higher increase in the debt/income ratio as combined with a similar NPL/debt ratio.

\section{Conclusion and Recommandations}

This paper has dealt with investigating the impact of rising households' NPLs on financial fragility in Tunisia. The major contributions were twofold. Firstly, we have applied the unit root test of Im, Pesaran and Shin (IPS, 2003) for dynamic panel data, which eliminates the risk of discovering any fallacious regressions. Secondly, we have resorted to the error-correction and cointegration tests of Pedroni (2004), which ensure the fact of checking the long-term equilibrium dynamic relationships among the variables in our model.

The detection of a cointegration relationship between the households' financial fragility indicator and the macroeconomic determinants has provided an undeniably interesting advantage at the practical level. In order to ascertain our results' reliability and robustness, we have primarily opted for the use of the ECM models. The obtained results have proven that the adjustment coefficients are negative and statistically significant, hence highlighting that the ECM actually confirms and corroborates Pedroni's findings (2004). 
Overall, our study has demonstrate that the applied variables in our model have really contributed in explaining a major proportion of the payment-default variation, underlying that the model has conveniently taken into account the factors leading to the rise of NPLs and consequently, the aggravating state of the Tunisian households' financial fragility.

\subsection{Recommandations}

Our findings show that Tunisian banks have to pay a greater attention to various factors when allocating loans in order to minimize the size of rejected or discarded due-installments and, above all, to minimize the doubtful loans' global level. In addition, the Tunisian banking sector should also consider the economy's real performance when extending the scope of their credits, as household NPLs are likely to reach even higher thresholds during economic-downturn and slow-down periods.

Ultimately, banks also need to extend their macro-economic monitoring framework in order to include prudential indicators and measures, such as the GDP, in order to ensure a high level of an effective evaluation of the banking system stability.

\section{References}

Anderloni, L., \& Vandone, D. (2010). Risk of Overindebtedness and Behavioural Factors. In C. Lucarelli, \& G. Brighetti (Eds.), Risk Tolerance In Financial Decision Making. Palgrave Macmillan. Retrieved from $\mathrm{http}: / /$ ssrn.com/abstract=1653513

Anderloni, L., Bacchiocchi, E., \& Vandone, D. (2012). Household Financial Vulnerability: An Empirical Analysis. Research in Economics, 66, 284-296. http://dx.doi.org/10.1016/j.rie.2012.03.001

Antzoulatos, A. A. (1996). Consumer credit and consumption forecast. International Journal on Forecasting, 12, 439-453. http://dx.doi.org/10.1016/S0169-2070(96)00687-5

Bacchetta, P., \& Gerlach, S. (1997). Consumption and Credit Constraints: International Evidence. Journal of Monetary Economics, 40, 207-238. http://dx.doi.org/10.1016/S0304-3932(97)00042-1

Bai, J., \& Ng, S. (2001). A PANIC Attack on Unit Roots and Cointegration. Mimeo, Boston College, Department of Economics.

Baltige, B., \& Griffin, J. (1997). Pooled estimators vs. their heterogeneous counterparts in the context of

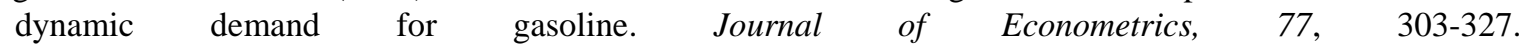
http://dx.doi.org/10.1016/S0304-4076(96)01802-7

Banerjee, A., Marcellino, M., \& Osbat, C. (2004). Some Cautions on the Use of Panel Methods for Integrated Series of Macroeconomic Data. The Econometrics Journal, 7, 322-340. http://dx.doi.org/10.1111/j.1368-423X.2004.00133.x

Bencivenga, V. R., Smith, B. D., \& Starr, R. M. (1996). Equity markets, transaction costs, and capital accumulation: An illustration. World Bank Economic Review, 10(2), 241-265. http://dx.doi.org/10.1093/wber/10.2.241

Bernard, A. B., \& Durlauf, S. N. (1996). Interpreting test of convergence hypothesis. Journal of Econometrics, 71, 161-174. http://dx.doi.org/10.1016/0304-4076(94)01699-2

Bertrand, M., Schoar, A., \& Thesmar, D. (2007). Banking Deregulation and Industry Structure: Evidence from the French Banking Reforms of 1985. Journal of Finance, 62, 597-628. http://dx.doi.org/10.1111/j.1540-6261.2007.01218.x

Bofondi, M., \& Ropele, T. (2011). Macroeconomic determinants of bad loans: Evidence from Italian banks. Occasional Papers, 89, 5-29.

Bridges, S., \& Disney, R. (2004). Use of credit and arrears on debt among low-income families in the United Kingdom. Fiscal Studies, 25, 1-25. http://dx.doi.org/10.1111/j.1475-5890.2004.tb00094.x

Brown, S., \& Taylor, K. (2008). Household debt and financial assets: Evidence from Germany, Great Britain and the USA. Journal of the Royal Statistical Society, 17, 615-643. http://dx.doi.org/10.1111/j.1467-985X.2007.00531.x

Carroll, C. D., \& Dunn, W. D. (1997). Unemployment Expectations, Jumping (S, s) Triggers, and Household Balance Sheets. In B. S. Bernanke, \& J. J. Rotemberg (Eds.), NBER Macroeconomics Annual 1997 (pp. 165-217). Cambridge, MA: MIT Press. http://dx.doi.org/10.2307/3585228

Chang, Y. (2002). Nonlinear IV Unit Root Tests in Panels with Cross-Sectional Depen dency. Journal of 
Econometrics, 110, 261-292. http://dx.doi.org/10.1016/S0304-4076(02)00095-7

Chang, Y. (2004). Bootstrap Unit Root Tests in Panels with Cross-Sectional Dependency. Journal of Econometrics, 120, 263-293. http://dx.doi.org/10.1016/S0304-4076(03)00214-8

Christelis, D., Jappelli, T., Paccagnella, O., \& Weber, G. (2010). Income, wealth and financial fragility in Europe. Journal of European Social Policy, (19), 359-376.

Davis, P., \& Zhu, H. (2004). Bank lending and commercial property cycles: Some cross-country evidence. BIS Working Papers no. 150.

Del Rio, A., \& Young, G. (2008). The impact of unsecured debt on financial pressure among British households. Applied Financial Economics, (18), 1209-1220. http://dx.doi.org/10.1080/09603100701604233

Dick, A. A., \& Lehnert, A. (2010). Personal Bankruptcy and Credit Market Competition. Journal of Finance, 65, 655-686. http://dx.doi.org/10.1111/j.1540-6261.2009.01547.x

Donovan, C., \& Schnure, C. (2011). Locked in the House: Do Underwater Mortgages Reduce Labor Market Mobility? Working Paper. Retrieved from http://ssrn.com/abstract=1856073

Duygan-Bump, B., \& Grant, C. (2009). Household Debt Repayment Behaviour: What Role do Institutions Play? Economic Policy, 24(57), 107-140. http://dx.doi.org/10.1111/j.1468-0327.2009.00215.x

Faruqui, U. (2008). Indebtedness and the Household Financial Health: An Examination of the Canadian Debt Service Ratio Distribution. Bank of Canada, Working Paper N. 46.

Fay, S., Hurst, E., \& White, M. (2002). The household bankruptcy decision. The American Economic Review, 92, 706-718. http://dx.doi.org/10.1257/00028280260136327

Fuenzalida, M., \& Ruiz-Tagle, J. (2009). Households' Financial Vulnerability. Central Bank of Chile, Working Paper N. 540, Chile.

Groen, J. J. J., \& Kleibergen, F. (2003). Likelihood-based cointegration analysis in panels of vector error correction models. Journal of Business and Economic Statistics, 21(2), 295-318. http://dx.doi.org/10.1198/073500103288618972

Harris, R. D. F., \& Tzavalis, E. (1999). Inference for unit roots in dynamic panels where the time dimension is fixed. Journal of Econometrics, 91, 201-226. http://dx.doi.org/10.1016/S0304-4076(98)00076-1

Im, K., Pesaran, H., \& Shin, Y. (1997). Testing for Unit Roots in Heterogeneous Panels. Mimeo, University of Cambridge, UK.

IMF. (2006). Household Credit Growth in Emerging Market Countries. Chapter 2 in Global Financial Stability Report: Market Development and Issues. International Monetary Fund, Washington, D.C, USA.

Jappelli, T., Pagano, M., \& Di Maggio, M. (2008). Households' indebtedness and financial fragility. CSEF Working Papers 208.

Kao, C. (1999). Spurious Regression and Residual-Based Tests for Cointegration in Panel Data. Journal of Econometrics, 90, 1-44. http://dx.doi.org/10.1016/S0304-4076(98)00023-2

Larsson, R., Johan, L., \& Mickael, L. (2001). Likelihood-based Cointegration Tests in Heterogeneous Panels. Econometrics Journal, 4, 109-142. http://dx.doi.org/10.1111/1368-423X.00059

Levin, A., \& Lin, C. F. (1992). Unit root tests in panel data: Asymptotic and finite sample properties. Discussion Paper, 56, Department of Economics, University of Califonia at San Diego, USA.

Levin, A., \& Lin, C. F. (1993). Unit root tests in panel data: New results. Discussion Paper 92-93, Department of Economics, University of California at San Diego, USA.

Levin, A., Lin, C. F., \& Chu, J. (2002). Unit root tests in panel data: Asymptotic and finite sample properties. Journal of Econometrics, 108, 1-24. http://dx.doi.org/10.1016/S0304-4076(01)00098-7

May, O., Tudela, M., \& Young, G. (2004). British household indebtedness and financial stress: A household-level picture. Bank of England Quarterly Bulletin, Winter, 414-428.

Pedroni, P. (1995). Panel Cointegration: Asymptotic and Finite Sample Properties of Pooled Time Series Tests with an Application to the PPP Hypothesis. Indiana University Working Paper in Economics, $\mathrm{N}^{\circ} .95-013$.

Pedroni, P. (1997). Panel Cointegration: Asymptotic and Finite Sample Properties of Pooled Time 28 Series Tests with an Application to the PPP Hypothesis: New Results. Indiana University Working Paper in Economics, USA. 
Pedroni, P. (1999). Critical values for cointegration tests in heterogeneous panels with multiple regressors. Oxford Bulletin of Economics and Statistics, 61, 653-670. http://dx.doi.org/10.1111/1468-0084.61.s1.14

Pedroni, P. (2004). Panel cointegration, asymptotic and finite sample properties of pooled time series tests with application to the PPP hypothesis. Econometric Theory, 20, 597-625. http://dx.doi.org/10.1017/S0266466604203073

Pesaran, M. H., Shin, Y., \& Smith, R. (1999). Pooled mean group estimation of dynamic heterogeneous panels. Journal of the American Statistical Association, 94, 621-634. http://dx.doi.org/10.1080/01621459.1999.10474156

Petersen, M., \& Rajan, R. (1994). The benefits of lending relationships: Evidence from small business data. Journal of Finance, 49, 1367-1400. http://dx.doi.org/10.1111/j.1540-6261.1994.tb04418.x

Rinaldi, L., \& Arellano, S. A. (2006). Household debt sustainability: What explains.

Rojas-Suarez, L. (2000). Can International Standards Strengthen Banks in Emerging Markets? Working Paper, Institute for International Economics.

Vandone, D. (2009). Consumer Credit in Europe: Risks and Opportunities of a Dynamic Industry. Springer-Verlag, Berlin, pp. 1-134. http://dx.doi.org/10.1007/978-3-7908-2101-7_1

Whitley, J., Windram, R., \& Cox, P. (2004). An empirical model of household arrears. Bank of England Working Paper no. 214, UK.

Worthington, A. C. (2006). Debt as a source of financial stress in Australian households. Journal of Consumer Research, 30, 2-15. http://dx.doi.org/10.1111/j.1470-6431.2005.00420.x

Yoo, S. H. (2006). Oil Consumption and Economics Growth: Evidence from Korea. Energy Sources, Part B, 13, 235-243.

\section{Notes}

Note 1. In fact, although homeowners represent the largest portion of debt due to their resorting to mortgages, renters have remained ascribed to debt problems since they are expected to face problems of servicing their unsecured debt more than homeowners do.

Note 2. Owing to the lack of data relevant to household real disposable income in the Tunisian contex, we have dealt with this variable by relying on Rinaldi et al. (2006).

Note 3. It is worth noting that the three ECM estimation techniques in panel (DFE, PMG and MGP) yield similar results as regard to the adjustment coefficient's significance and sign. In the present work, only the DFE estimation techniques were considered.

\section{Copyrights}

Copyright for this article is retained by the author(s), with first publication rights granted to the journal.

This is an open-access article distributed under the terms and conditions of the Creative Commons Attribution license (http://creativecommons.org/licenses/by/3.0/). 